\title{
Resistance to the Ug99 Race Group of Puccinia graminis f. sp. tritici in Wheat-Intra/intergeneric Hybrid Derivatives
}

Joshua Kielsmeier-Cook, Department of Plant Pathology, University of Minnesota, St. Paul 55108; Tatiana V. Danilova and Bernd Friebe, Wheat Genetics Resource Center, Department of Plant Pathology, Kansas State University, Manhattan 66506; and Matthew N. Rouse, Cereal Disease Laboratory, United States Department of Agriculture, St. Paul, MN and Department of Plant Pathology, University of Minnesota, St. Paul

\begin{abstract}
Kielsmeier-Cook, J., Danilova, T. V., Friebe, B., and Rouse, M. N. 2015. Resistance to the Ug99 lineage of Puccinia graminis f. sp. tritici in wheat-intra/intergeneric derivatives. Plant Dis. 99:1317-1325.

New races of Puccinia graminis f. sp. tritici, the causal agent of stem rust, threaten global wheat production. In particular, races belonging to the Ug99 race group significantly contribute to yield loss in several African nations. Genetic resistance remains the most effective means of controlling this disease. A collection of 546 wheat-intra- and intergeneric hybrids developed by W. J. Sando (United States Department of Agriculture, Beltsville, MD) was screened with eight races of $P$. graminis $\mathrm{f}$. sp. tritici, including races TTKSK, TTKST, TTTSK, TRTTF, TTTTF, TPMKC, RKQQC, and QTHJC. There were 152 accessions resistant to one or more races and 29 accessions resistant to TTKSK, TTKST, and TTTSK. Of these 29 accessions, 9 were resistant to

all races, 14 had infection type patterns that were indistinguishable from cultivars possessing $\mathrm{Sr} 9 \mathrm{~h}$ and $\mathrm{Sr} 42$, 2 were indistinguishable from accessions with SrTmp, and 4 did not display resistant patterns of accessions with any known Sr gene. Three accessions $(604981,605286$, and 611932) characterized cytogenetically were disomic substitution lines, each with a single Thinopyrum ponticum chromosome pair. One accession (606057) was a disomic substitution or addition line with two pairs of $T$. ponticum chromosomes. In total, seven accessions are postulated to contain novel stem rust resistance genes. This research indicates the value of extant collections of wheat-intergeneric hybrids as sources of disease resistance genes.
\end{abstract}

Despite more than a century of research, wheat stem rust, caused by Puccinia graminis f. sp. tritici Erikss. \& Henning, continues to threaten global wheat (Triticum aestivum L.) production. Although this disease has been controlled effectively via genetic resistance in Europe and North America since 1951 and 1974, respectively, localized severe epidemics of stem rust in East Africa, caused by new races of $P$. graminis f. sp. tritici, serve to remind wheat scientists that, indeed, "rust never sleeps" $(31,62)$. The stem rust races responsible for these epidemics are predominantly members of the Ug99 race group, socalled due to a $P$. graminis f. sp. tritici isolate discovered in the highlands of Uganda in 1998 and named in 1999 (50). This isolate was typed as race TTKS, in accordance with the international stem rust nomenclature system, and was particularly alarming due to the isolate's virulence on the widely deployed stem rust resistance gene $\operatorname{Sr} 31$ $(57,70)$. Subsequent wheat nursery screenings at the Kenya Agricultural Research Institute in Njoro, Kenya revealed that the majority of wheat cultivars grown in countries threatened by potential TTKS migration routes were susceptible (62). The discovery of two races in Kenya similar to TTKS but with additional virulence to the resistance genes Sr24 (TTKST) and Sr36 (TTTSK) prompted the revision of the international nomenclature system with the addition of a fifth gene set in the differential series: genes $\operatorname{Sr} 24, \operatorname{Sr} 31, \operatorname{Sr} 38$, and SrMcn $(19,20)$. Currently, the Ug99 race group is comprised of eight races: PTKSK, PTKST, TTKSF, TTKSK (Ug99), TTKSP, TTKST, TTTSK, and TTKSF+ $(48,51)$. One or more of these races have been found in South Africa, Zimbabwe, Mozambique, Tanzania, Rwanda, Kenya, Uganda, Ethiopia, Sudan, Eritrea, Yemen, and Iran $(51,61,67)$.

There are at least 33 wheat stem rust resistance genes $(\mathrm{Sr})$ that provide resistance against various members of the $\mathrm{Ug} 99$ race group: $\mathrm{Sr} 2$,

Corresponding author: J. Kielsmeier-Cook; E-mail: kiels008@umn.edu

*The $\boldsymbol{e}$-Xtra logo stands for "electronic extra" and indicates that two supplementary tables are included in the online edition.

Accepted for publication 4 March 2015.

http://dx.doi.org/10.1094/PDIS-09-14-0922-RE

(C) 2015 The American Phytopathological Society
Sr9h, Sr13, Sr21, Sr22, Sr24, Sr25, Sr26, Sr27, Sr28, Sr32, Sr33, Sr35, Sr36, Sr37, Sr39, Sr40, Sr42, Sr43, Sr44, Sr45, Sr46, Sr47, Sr50, Sr51, Sr52, Sr53, Sr57 (Lr34), SrTA10171, SrTA10187, SrTA1662, SrTmp, and SrlRS Amigo $(9,14,15,17,18,29,34,35,42,46,47,53,59,60,63)$. Of these 33 genes, only 5 are derived from $T$. aestivum. Source species for the remaining 27 genes include T. turgidum Flaksb., T. monoccocum subsp. monoccocum L. Flaksb., T. timopheevii subsp. timopheevii (Zhuk.) Zhuk., T. timopheevii subsp. armeniacum (Jakubz.) MacKey, Aegilops comosa $\mathrm{Sm}$. in Sibth. \& Sm. var. comosa, A. ventricosa Tausch, A. speltoides Tausch var. speltoides, A. tauschii Cross, Thinopyrum ponticum (Podp.) Barkworth and D. R. Dewey (syn. Agropyron elongatum (Host) Beauvois), and T. intermedium (Host) Barkworth and D. R. Dewey (syn. A. intermedium (Host) Beauvois). Singh et al. (61) listed the barriers to the large-scale deployment of these genes, including linkage with undesirable agronomic traits, known virulence in other races of $P$. graminis f. sp. tritici, or ineffective levels of resistance conferred under high inoculum loads. Yet despite the continued erosion of resistance and barriers to gene deployment, host genetic resistance remains the most effective form of disease control available, and several groups have reviewed the importance of alien gene transfer for disease resistance in wheat $(12,21,71)$.

One effective strategy to discover and rapidly develop new sources of resistance is the focused stem rust screening of existing collections of wheat-intra- and intergeneric hybrids. The W. J. Sando collection of intra- and intergeneric hybrids was created by W. J. Sando (United States Department of Agriculture [USDA], Beltsville, MD) during the first half of the 20th century. Species used for hybrid breeding with Triticum aestivum included Aegilops spp., Secale cereale, Thinopyium intermedium, T. ponticum, Triticum timopheevii, and T. turgidum subsp. durum. Early research with wheat-intergeneric hybrids, including that of W. J. Sando, was spurred by the pursuit of perennial grain and forage crops as well as disease resistance $(55,64)$. Although perennial material of agronomic value eluded early researchers, disease-resistant material did result from this work, including material developed by W. J. Sando (55). Of note, crosses made with selections from a Sando line resulted in wheat cultivar 'Agent', the modern source of $\operatorname{Sr} 24(12,65)$. In more recent work, accessions from the Sando collection have shown resistance to eyespot (Oculimacula yallundae (Wallwork \& Spooner) Crous \& W. Gams; synonym Tapesia yallundae), Cephalosporium stripe (Hymenula cerealis Ellis \& Everh.), scab (Gibberella zeae (Schwein.) Petch; 
synonym Fusarium graminearum Schwabe), Stagnospora blotch (Parastagonospora nodorum (Berk.) Quaedvl., Verkley \& Crous.; synonym Stagonospora nodorum (Berk.) E. Castell. \& Germano), tan spot (Pyrenophora tritici-repentis (Died.) Dreschler), wheat streak mosaic (Wheat streak mosaic virus), barley yellow dwarf (Barley yellow dwarf virus), and stem rust (Puccinia graminis f. sp. tritici) $(1,5,43,71)$.

To our knowledge, there is no published work characterizing the Sando collection for seedling stem rust resistance. Therefore, we screened the 546 accessions of the W. J. Sando collection available from the USDA National Small Grains Collection in Aberdeen, ID. Our goal was to identify accessions resistant to the Ug99 race group and characterize these accessions cytogenetically in order to select promising material for further manipulation and introgression.

\section{Materials and Methods}

Plant material and stem rust screening. In total, 546 accessions of the W. J. Sando Collection were obtained from the USDA National Small Grains Collection (Aberdeen, ID). The accessions were each screened with eight races of $P$. graminis $\mathrm{f}$. sp. tritici. Stem rust races TTKSK, TTKST, TTTSK, and TRTTF were selected for the isolates' broad virulence and prevalence in African stem rust epidemics (Table 1). North American stem rust races TTTTF, TPMKC, RKQQC, and QTHJC were also used for screening (Table 1). All stem rust races used are maintained at the USDA Agricultural Research Service (ARS) Cereal Disease Laboratory in St. Paul, MN.

Urediniospores were collected from infected wheat seedlings (for race TTKST) or removed from storage in $-80^{\circ} \mathrm{C}$ freezers (for all other races). Urediniospores removed from storage were heat shocked at $45^{\circ} \mathrm{C}$ for $15 \mathrm{~min}$ and placed in a rehydration chamber maintained at $80 \%$ relative humidity using a $\mathrm{KOH}$ solution for 2 to $4 \mathrm{~h}$. Newly produced urediniospores (TTKST) were collected from plants, placed into gelatin capsules, and immediately inoculated onto seedlings following suspension in a light mineral oil (Soltrol 170; Chevron Phillips Chemical Co. LP, The Woodlands, Texas). New and stored urediniospores were inoculated onto seedlings following previously described methods (18). Plants were scored for Stakman seedling infection types (IT) at 14 days postinoculation (66). Accessions with an IT of " 0 ", ";," "1", and "2" or a combination thereof were considered resistant. Accessions with an IT of " 3 " or " 4 " were considered susceptible. Each assay contained five to eight plants of each accession. If plants of a single accession segregated for resistance, the accession was considered heterogeneous. All assays were performed in duplicate.

Data analysis. Statistical analysis of accessions and their racespecific resistance or susceptibility patterns was performed using $\mathrm{R}$ version 3.0.2 (http://www.r-project.org) in RStudio (http://www.rstudio. com/products/rstudio/\#Desk). A multiple correspondence analysis (MCA) was performed using the R package 'ca' version 0.53 (41). MCA, based on the work of Benzérci and colleagues (2), can explain underlying patterns in complex data sets and is an appropriate alternative to principal coordinate analysis when the data to be analyzed are categorical (as in, "Resistant" or "Susceptible") instead of quantitative (3).
MCA can be used to visualize the spatial relationships among the "responses"-namely, susceptible (S) and resistant (R)—of accessions to individual races of $P$. graminis $\mathrm{f}$. sp. tritici (i.e., how resistance to TTKSK correlates with resistance to all other races). In total, 152 accessions displaying a resistant IT to one or more races were analyzed. For simplicity, only those accessions resistant in all replications were coded as "R"; all other accessions were coded as "S", even if the mixed reactions included an R and S IT. ITs of $1+3$ and $2+3$ were considered susceptible reactions, and were coded as "S". The MCA was performed using a dataframe in which the qualitative variables (columns) were the eight races of $P$. graminis $\mathrm{f}$. sp. tritici and the observations (rows) were reactions of individual accessions to each race. The analysis was run with the variable $\lambda$ as " $\lambda$ = adjusted", in which the analysis is based on a Burt matrix with adjusted inertias, and the number of dimensions (nd) to be included in the output as nd $=5$ (41).

Molecular marker screening of selected accessions. Plant introduction (PI) accessions 604981, PI 605057, PI 605286, and PI 611932 were screened with the molecular markers Xbarc71 (Sr24), $G b$ (Sr25), and BE518379/Sr26\#43 (Sr26). Leaf tissue for each accession was collected at the seedling stage (approximately 7 days after germination) and total DNA was extracted using a modified cetyltrimethylammonium bromide method (58). Published protocols were followed for all polymerase chain reactions (PCR) involving these markers $(32,37)$.

Cytogenetic examination of selected accessions. Nine resistant accessions were examined using the root squash method outlined below to count the number of chromosomes present. Briefly, rootlets of germinated seed were cut when 1.5 to $2.0 \mathrm{~cm}$ long, placed in 2-ml glass vials containing double-distilled $\mathrm{H}_{2} \mathrm{O}$, and cooled to $1^{\circ} \mathrm{C}$ in an ice-water bath for 20 to $24 \mathrm{~h}$. Roots were fixed in $2 \mathrm{ml}$ of Carnoy's solution (1:3 glacial acetic acid/absolute ethanol) and stored at $4^{\circ} \mathrm{C}$ until examined. For chromosome examination, roots were stained in a $1 \%$ acetocarmine solution for 1 to $3 \mathrm{~h}$. Root caps were then removed with a razor blade and the meristematic tissue was squeezed out with a lancet needle. Meristematic tissue was placed on a glass slide in a single drop of $1 \%$ acetocarmine, carefully compressed, and covered with a glass slide. Prepared slides were heated to just below boiling and final compression was performed manually. A minimum of three rootlets was examined for each accession. Observations were made using a Zeiss Photomicroscope III (Carl Zeiss AG, Oberkochen, Germany).

Accessions resistant to race TTKSK and initially found to possess 42 chromosomes were assessed for the presence of Thinopyrum ponticum DNA using genomic in situ hybridization (GISH), with genomic DNA (gDNA) from $T$. ponticum as a probe (74). To detect the homeologous group of $T$. ponticum chromosomes, these accessions were submitted to combined fluorescence in situ hybridization (FISH) and GISH procedures, using GAA and pAs1 oligonucleotide probes to identify individual wheat chromosomes and a $T$. ponticum gDNA probe to identify alien chromosomes (6). It was assumed that the missing wheat chromosomes were substituted by $T$. ponticum homeologs. The FISH-GISH procedure followed modified protocols

Table 1. Virulence or avirulence formulae of Puccinia graminis f. sp. tritici isolates used to screen the W. J. Sando collection of wheat-intra- and intergeneric hybrids and derivatives from the United States Department of Agriculture

\begin{tabular}{lcc}
\hline Isolate $^{\mathbf{a}}$ & Race $^{\mathbf{b}}$ & \multicolumn{1}{c}{ Virulence and avirulence $^{\mathbf{c}}$} \\
\hline 04KEN156-04 & TTKSK & $5,6,7 \mathrm{~b}, 8 \mathrm{a}, 9 \mathrm{a}, 9 \mathrm{~b}, 9 \mathrm{~d}, 9 \mathrm{e}, 9 \mathrm{~g}, 10,11,17,21,30,31,38, \mathrm{McN} / 24,36, \mathrm{Tmp}$ \\
06KEN19-V 3 & TTKST & $5,6,7 \mathrm{~b}, 8 \mathrm{a}, 9 \mathrm{a}, 9 \mathrm{~b}, 9 \mathrm{~d}, 9 \mathrm{e}, 9 \mathrm{~g}, 10,11,17,21,24,30,31,38, \mathrm{McN} / 36, \mathrm{Tmp}$ \\
07KEN24-4 & TTTSK & $5,6,7 \mathrm{~b}, 8 \mathrm{a}, 9 \mathrm{a}, 9 \mathrm{~b}, 9 \mathrm{~d}, 9 \mathrm{e}, 9 \mathrm{~g}, 10,11,17,21,30,31,36,38, \mathrm{McN} / 24, \mathrm{Tmp}$ \\
06YEM34-1 & TRTTF & $5,6,7 \mathrm{~b}, 9 \mathrm{a}, 9 \mathrm{~b}, 9 \mathrm{~d}, 9 \mathrm{e}, 9 \mathrm{~g}, 10,11,17,21,30,36,38, \mathrm{McN}, \mathrm{Tmp} / 8 \mathrm{a}, 24,31$ \\
74MN1409 & TPMKC & $5,7 \mathrm{~b}, 8 \mathrm{a}, 9 \mathrm{~d}, 9 \mathrm{e}, 9 \mathrm{~g}, 10,11,17,21,36, \mathrm{McN}, \mathrm{Tmp} / 6,9 \mathrm{a}, 9 \mathrm{~b}, 24,30,31,38$ \\
01MN84A-1-2 & TTTTF & $5,6,7 \mathrm{~b}, 8 \mathrm{a}, 9 \mathrm{a}, 9 \mathrm{~b}, 9 \mathrm{~d}, 9 \mathrm{e}, 9 \mathrm{~g}, 10,11,17,21,30,36,38, \mathrm{McN}, \mathrm{Tmp} / 24,31$ \\
75 ND717-C & QTHJC & $5,6,8 \mathrm{a}, 9 \mathrm{~b}, 9 \mathrm{~d}, 9 \mathrm{~g}, 10,11,17,21, \mathrm{McN} / 9 \mathrm{a}, 9 \mathrm{e}, 7 \mathrm{~b}, 24,30,31,36,38, T \mathrm{Tmp}$ \\
99KS76A & RKQQC & $5,6,7 \mathrm{~b}, 8 \mathrm{a}, 9 \mathrm{a}, 9 \mathrm{~b}, 9 \mathrm{~d}, 9 \mathrm{~g}, 21,36, \mathrm{McN} / 9 \mathrm{e}, 10,11,17,24,30,31,38, T \mathrm{Tmp}$
\end{tabular}

${ }^{\text {a }}$ The first two numbers indicate the year in which the isolate was collected; KEN = Kenya, YEM = Yemen, MN = Minnesota, ND = North Dakota, and KS = Kansas.

${ }^{b}$ For an explanation of stem rust race nomenclature, see Roelfs and Martens (57).

c All stem rust resistance genes listed are part of the International Wheat Stem Rust differential series (19,20). For details concerning each gene, see McIntosh et al. (40). 
from Zhang et al. (74). After removing cover slips from frozen squashed preparations, slides were immersed in $100 \%$ ethanol for $5 \mathrm{~min}$, dried, and UV cross-linked. The probe mixture ( $20 \mu \mathrm{l} / \mathrm{slide})$ contained 50\% formamide (Fisher Scientific, Pittsburgh), 2.75x saline-sodium citrate (SSC) buffer, $13.75 \%$ dextran sulfate, $2.4 \mu \mathrm{g}$ of wheat-blocking gDNA, $40 \mathrm{ng}$ of $T$. ponticum gDNA probe, $1 \mathrm{ng}$ of Cy5-(GAA) $)_{9}$, and $60 \mathrm{ng}$ of TEX615-pAs1-oligonucleotide probes (Integrated DNA Technologies, Inc., Coralville, IA). The mixture of probes and the slide preparations were denatured separately in $100^{\circ} \mathrm{C}$ water. The remainder of the FISH+GISH procedures followed the protocol of Kato et al. (22). Slides were incubated at $37^{\circ} \mathrm{C}$ overnight and washed twice in $2 \times \mathrm{SSC}$ buffer $(1 \times \mathrm{SSC}$ is $0.15 \mathrm{M} \mathrm{NaCl}$ plus $0.015 \mathrm{M}$ sodium citrate): $5 \mathrm{~min}$ at room temperature, $10 \mathrm{~min}$ at $42^{\circ} \mathrm{C}$, and then in $1 \times \mathrm{SSC}$ buffer for $5 \mathrm{~min}$ at room temperature. Chromosome preparations were mounted and counterstained with 4',6-diamidino-2phenylindole solution or propidium iodide in Vectashield (Vector Laboratories Inc., Burlingame, CA). Images were captured with a Zeiss Axioplan 2 microscope using a cooled charge-coupled device camera (CoolSNAP HQ2; Photometrics, Tuscon, AZ) and AxioVision 4.8 software (Carl Zeiss AG). Images were processed using the Adobe Photoshop software (Adobe Systems Incorporated, San Jose, CA).

\section{Results}

Seedling resistance to stem rust. The W. J. Sando collection was found to harbor 152 accessions with resistance to one or more races of $P$. graminis f. sp. tritici. The number of accessions resistant to the individual races in the Ug99 race group, TTKSK, TTKST, and TTTSK, ranged from 52 to 64 (Table 2). Races TRTTF and TPMKC were virulent on the greatest number of accessions, with only 25 of 546 accessions resistant to each. Race RKQQC was the least virulent, with 79 accessions displaying resistance to this race in both replications. Full results of the screening are available in Supplementary Table S1.

The reactions of the wheat accessions to race TTKSK were correlated significantly with reactions to races TTKST $(r=0.496$ at $P<$ $0.0001)$, TTTSK $(r=0.480$ at $P<0.0001)$, and QTHJC $(r=0.210$ at $P=0.009)$, more so than can be expected under the assumption of independence (Table 3 ). Reactions to race TTTSK were also significantly correlated with reactions to races TTKST $(r=0.365$ at $P<0.0001)$ and RKQQC $(r=0.221$ at $P=0.006)$. In comparison, reactions to TRTTF were correlated significantly with reactions to races TTTTF $(r=0.317$ at $P<0.0001)$ and TPMKC $(r=0.425$ at $P<0.0001)$. Reactions to races TTTTF and TPMKC $(r=0.411$ at $P<0.0001)$ were also highly correlated (Table 3).

The first dimension (x-axis) of the MCA explained $64.6 \%$ of the variance between the wheat accession reactions to the eight races of

Table 2. Percentages of W. J. Sando wheat accessions resistant, heterogeneous, and susceptible to each of eight physiologic races of Puccinia graminis f. sp. tritici $i^{\mathrm{a}}$

\begin{tabular}{lcccc}
\hline Race $^{\mathbf{b}}$ & Total $^{\mathbf{c}}$ & Resistant $^{\mathbf{d}}$ & Heterogeneous $^{\mathbf{e}}$ & Susceptible $^{\mathbf{f}}$ \\
\hline TTKSK & 546 & $64(11.72 \%)$ & $67(12.27 \%)$ & $415(76.01 \%)$ \\
TTKST & 542 & $59(10.89 \%)$ & $70(12.92 \%)$ & $413(76.20 \%)$ \\
TTTSK & 544 & $52(9.56 \%)$ & $89(16.36 \%)$ & $403(74.08 \%)$ \\
TRTTF & 544 & $25(4.60 \%)$ & $51(9.38 \%)$ & $468(86.03 \%)$ \\
TTTTF & 545 & $26(4.77 \%)$ & $102(18.72 \%)$ & $417(76.51 \%)$ \\
TPMKC & 545 & $25(4.59 \%)$ & $37(6.79 \%)$ & $483(88.62 \%)$ \\
QTHJC & 536 & $50(9.33 \%)$ & $53(9.89 \%)$ & $433(80.78 \%)$ \\
RKQQC & 542 & $79(14.58 \%)$ & $115(21.22 \%)$ & $348(64.21 \%)$
\end{tabular}

a Seedlings were scored using the seedling infection type scale created by Stakman et al. (66).

${ }^{b}$ For an explanation of stem rust race nomenclature, see Roelfs and Martens (57).

c Totals are not equal among races due to the lack of seed germination in some replications.

d Accessions displayed resistant infection types (";" to "2") in all replications.

e Accessions displayed a mixture of resistant and susceptible infection types in one or more replication.

f Accessions displayed susceptible infection types (“3" or " 4 ') in all replications. stem rust and separated resistant reactions from susceptible reactions, designating resistant reactions with positive values and susceptible reactions with negative values (Fig. 1). This also separated resistance to less virulent races QTHJC and RKQQC from resistance to the six more virulent races. The second dimension (y-axis) explained $11.4 \%$ of the variance between the wheat accession reactions to the eight races

Table 3. Significant correlations between wheat accessions of the W. J. Sando collection resistant to one or more races of Puccinia graminis $\mathrm{f}$. sp. tritici and reactions to eight different races of $P$. graminis f. sp. tritici ${ }^{\mathrm{a}}$

\begin{tabular}{|c|c|c|c|}
\hline \multicolumn{2}{|c|}{ Correlation between } & \multirow[b]{2}{*}{$r^{\mathbf{c}}$} & \multirow[b]{2}{*}{$P$ value $(<0.05)^{\mathrm{d}}$} \\
\hline Race $^{\text {b }}$ & Race & & \\
\hline TTKSK & TTKST & 0.496 & $7.76 \times 10^{-11}$ \\
\hline TTKSK & TTTSK & 0.480 & $3.75 \times 10^{-9}$ \\
\hline TTKST & TTTSK & 0.365 & $3.85 \times 10^{-6}$ \\
\hline TTKSK & QTHJC & 0.210 & 0.009 \\
\hline TTTSK & RKQQC & 0.221 & 0.006 \\
\hline TRTTF & TTTTF & 0.317 & $6.96 \times 10^{-5}$ \\
\hline TRTTF & TPMKC & 0.425 & $4.63 \times 10^{-8}$ \\
\hline TTTTF & ТPMKC & 0.411 & $1.48 \times 10^{-7}$ \\
\hline TPMKC & QTHJC & 0.263 & 0.001 \\
\hline TPMKC & RKQQC & 0.178 & 0.028 \\
\hline
\end{tabular}

${ }^{a}$ Resistant accessions are those that displayed resistant infection types in both replications based on the seedling infection type scale developed by Stakman et al. (66). All correlations shown are positive.

${ }^{b}$ For an explanation of stem rust race nomenclature, see Roelfs and Martens (57).

c Pearson's product moment correlations coefficient (49).

d The $P$ value is the probability, under the null hypothesis of independence, of obtaining a result equal to or more extreme than that observed. Usually $P$ values $<0.05$ or 0.01 are considered to significantly deviate from the null hypothesis (10).

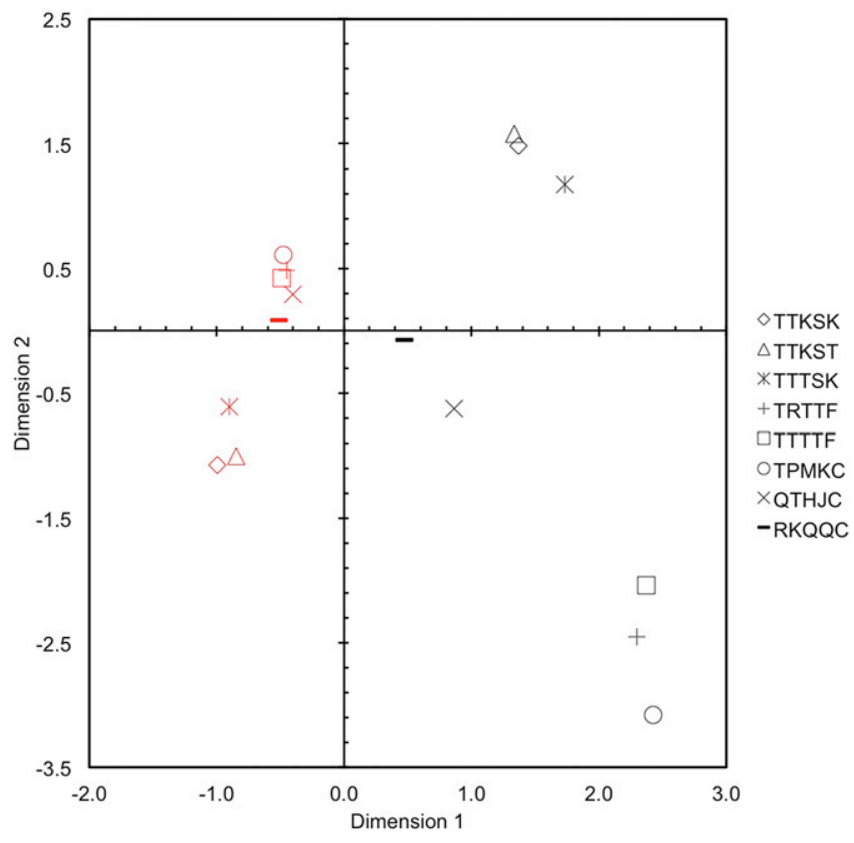

Fig. 1. Biplot showing relationships between resistance and susceptibility of 152 resistant W. J. Sando collection wheat accessions to eight races of Puccinia graminis f. sp. tritici. Races are named according to the international stem rust race nomenclature $(19,20,57)$. Resistant accessions are those displaying resistant infection types according to Stakman et al. (66) in both replications in which a race was evaluated. Susceptible accessions are those that displayed a susceptible reaction in at least one replication of the assays. Data points were derived using a multiple correspondence analysis in the statistical platform $\mathrm{R}$ using the package "ca" $(41,54)$. The $x$ - and $y$-axes explained 64.64 and $11.35 \%$, respectively, of the variation among accession reactions to the eight races of $P$. graminis f. sp. tritici. Red symbols = susceptibility to the associated race and black symbols = resistance to the associated race. 
of stem rust and discriminated resistance into three clusters: (i) the Ug99 race group; (ii) races RKQQC and QTHJC; and (iii) races TTTTF, TPMKC, and TRTTF (Fig. 1). The second dimension also distinguished susceptibility to races possessing virulence on Sr31 (TTKSK, TTKST, and TTTSK) from susceptibility to races avirulent on $\mathrm{Sr} 31$ (TRTTF, TTTTF, TPMKC, QTHJC, and RKQQC) (Fig. 1).

Molecular markers. None of the four accessions subjected to molecular marker screening (PI 604981, PI 605057, PI 605286, and

Table 4. Results of molecular marker screening of W. J. Sando wheat accessions selected for cytogenetic characterization using genomic in situ hybridization and fluorescence in situ hybridization (GISH-FISH) ${ }^{\mathrm{a}}$

\begin{tabular}{lccc}
\hline & \multicolumn{3}{c}{ Marker $^{\mathbf{b}}$} \\
\cline { 2 - 4 } Accessionc $^{\text {Xbarc71 }}$ & $-^{\mathrm{d}}$ & $\boldsymbol{G b}$ & BE518379/Sr26\#43 \\
\hline PI 604981 & - & - & - \\
PI 605057 & - & - & - \\
PI 605286 & - & - & - \\
PI 611932 & & - & + \\
\hline
\end{tabular}

${ }^{a}$ For GISH-FISH methods, see Materials and Methods section and references 6,22 , and 74 .

b These molecular markers are associated with stem rust resistance genes derived from Thinopyrum ponticum: Sr24 (Xbarc71), Sr25 (Gb), and Sr26 (BE518379/Sr26\#43) (32,37).

c All accessions contained the decaploid tall wheatgrass Thinopyrum ponticum (syn. Agropyron elongatum) in their pedigree (http://www.ars-grin. gov/npgs/acc/acc_queries.html).

$\mathrm{d} ;-$ and + indicate that the accession was negative or positive, respectively, for the stem rust resistance gene marker.
PI 611932) amplified the $S r 24$ (Xbarc71) marker, PI 604981 amplified the $\operatorname{Sr} 25(\mathrm{~Gb})$ marker, and PI 611932 amplified the Sr26 (BE518379/Sr26\#43) marker (Table 4).

Resistance to the Ug99 race group. Of the 152 resistant accessions, 29 were resistant to races TTKSK (Ug99), TTKST, and TTTSK combined. The pedigrees for these accessions are listed in Supplementary Table S2. The 29 Ug99-resistant accessions clustered into seven different race-specific IT patterns (Table 5). The most common pattern, exhibited by 14 of 29 accessions, combined resistance to the Ug99 race group with resistance to the North American race RKQQC. Accessions sharing this pattern are referred to as group 1. Resistant ITs in group 1 were "2-" to "2+" (PI 605023 exhibited IT " $2+3$ " in one replication with TTKSK). Nine accessions resistant to the Ug99 race group were also resistant to all other races used for screening. These accessions are referred to as group 2. Resistant ITs in group 2 ranged from "0;" to "2-" (PI 604981, 604986, 611887, and 611915 displayed higher ITs in some replications to some races) (Table 5). Group 3 accessions PI 605079 and PI 605321 displayed expected race-specific resistance patterns and ITs for lines possessing the resistance gene SrTmp. Groups 4 to 7 displayed unique resistance or susceptibility patterns that are not readily associated with any single known $\mathrm{Sr}$ gene.

Cytogenetics of selected resistant accessions. Nine accessions selected for resistance to race TTKSK were analyzed using the root squash method to determine the number of chromosomes present. Accessions PI 604924, PI 605132, PI 611887, and PI 611899 had chromosome counts of $2 n=54$. PI 605103 had individual root tips that displayed chromosome counts of $2 n=54,55$, and 56. The remaining accessions (PI 604981, PI 605057, PI 605286, and

Table 5. Infection types (IT), grouped by race-specific pattern, of 29 W. J. Sando collection wheat accessions resistant to Puccinia graminis f. sp. tritici races TTKSK, TTKST, and TTTSK ${ }^{\mathrm{a}}$

\begin{tabular}{|c|c|c|c|c|c|c|c|c|c|c|c|c|c|c|c|c|c|}
\hline \multirow[b]{3}{*}{ Accession } & \multirow[b]{3}{*}{ Group $^{c}$} & \multicolumn{16}{|c|}{ Race $^{\mathbf{b}}$} \\
\hline & & \multicolumn{2}{|c|}{ TTKSK } & \multicolumn{2}{|c|}{ TTKST } & \multicolumn{2}{|c|}{ TTTSK } & \multicolumn{2}{|c|}{ TRTTF } & \multicolumn{2}{|c|}{ TTTTF } & \multicolumn{2}{|c|}{ TPMKC } & \multicolumn{2}{|c|}{ QTHJC } & \multicolumn{2}{|c|}{ RKQQC } \\
\hline & & $\overline{\operatorname{Rep} 1}$ & $\overline{\operatorname{Rep} 2}$ & $\operatorname{Rep} 1$ & $\operatorname{Rep~} 2$ & $\operatorname{Rep} 1$ & $\overline{\operatorname{Rep} 2}$ & $\operatorname{Rep~} 1$ & $\overline{\operatorname{Rep} 2}$ & $\overline{\operatorname{Rep} 1}$ & $\overline{\operatorname{Rep} 2}$ & $\operatorname{Rep~} 1$ & $\operatorname{Rep~} 2$ & Rep 1 & Rep 2 & Rep 1 & Rep 2 \\
\hline PI 604868 & Group 1 & $22+$ & 2 & 2 & 2 & 2 & 2 & - & $3+$ & $3+$ & $3+$ & 4 & $3+$ & $3+$ & - & 2 & - \\
\hline PI 604890 & Group 1 & 2 & 2 & $2-C$ & - & $2-C$ & 2 & $3+$ & 3 & 2 & $3-$ & $3+$ & 3 & 4 & 4 & - & 2 \\
\hline PI 604905 & Group 1 & 2 & $22+$ & 2 & 2 & $2-$ & 2 & $3+$ & 3 & 23 & $3+$ & $3+$ & 4 & $3+$ & 4 & 2 & 2 \\
\hline PI 605016 & Group 1 & $2 \mathrm{C}$ & $2 / 22+$ & $2-$ & 2 & - & $2-$ & $3+$ & 3 & 3 & 3 & - & 3 & $1+$ & $3+$ & $2+$ & 2 \\
\hline PI 605022 & Group 1 & $2 / 2 \mathrm{C}$ & 2 & $2-$ & - & $2-$ & $2-$ & $3+4$ & $3+$ & $2+3$ & - & $3+$ & 4 & $3+\mathrm{LIF}$ & $3+$ & 2 & 2 \\
\hline PI 605023 & Group 1 & 2 & $2+3$ & 2 & 2 & $2-$ & $2-$ & $3+$ & 3 & $2+$ & 3 & - & 4 & $3+$ & $3+$ & 2 & 2 \\
\hline PI 605039 & Group 1 & $22+$ & 2 & 2 & 2 & $2-$ & 2 & $3+$ & $3+$ & 3 & $3+$ & $3+$ & $3+$ & 3 & - & 2 & 2 \\
\hline PI 605106 & Group 1 & 2 & $2 \mathrm{CN}$ & 2 & 2 & $2-$ & $2-$ & $3+$ & $3+$ & $2-$ & $3+4$ & $3+$ & $3+$ & 4 & 4 & 2 & $2+$ \\
\hline PI 605107 & Group 1 & 2 & $2 \mathrm{CN}$ & $2-$ & 2 & 2 & 2 & $3+$ & $3+$ & 2 & 3 & 3 & $3+$ & $3+$ & 3 & 2 & 2 \\
\hline PI 605185 & Group 1 & 2-LIF & $22+$ & 2 & 2 & 2 & 2 & $3+$ & $3+$ & 2 & 3 & 4 & 4 & $3+$ & 4 & 2 & 2 \\
\hline PI 605188 & Group 1 & $0 ; / 2$ & 2 & 2 & 2 & 2 & 2 & $3+$ & $3+$ & 2 & 3 & 3 & 4 & - & 4 & 2 & $2+$ \\
\hline PI 605245 & Group 1 & 2 & 2 & $2-$ & 2 & 2 & 2 & $3+$ & $3+$ & $3-$ & 3 & 3 & $3+$ & $3+$ & 4 & 2 & $2+$ \\
\hline PI 605317 & Group 1 & 2 & 2 & 2 & 2 & $2-$ & 2 & $3+$ & $3+$ & 4 & 3 & $3+$ & 3 & $3+$ & $3+$ & 2 & 2 \\
\hline PI 611927 & Group 1 & 2 & 2 & 2 & 2 & 2 & 2 & 3 & 2 & 31 & 3 & 3 & 3 & $2-$ & 3 & 2 & $2+$ \\
\hline PI 604924 & Group 2 & 0 & 0 & 0 & 0 & 0 & 0 & 0 & 0 & 0 & 0 & 0 & 0 & - & 0 & 0 & 0 \\
\hline PI 604981 & Group 2 & 0 & $; 1$ & 0 & $; 1$ & 2 & 0 & $3-; / 0$ & $0 ; 1 / ; 13$ & ; & 0 & ;3 & $0 ; 3$ & $1 ;$ & 1 & 0 & 0 \\
\hline PI 604986 & Group 2 & 2 & 2 & $1 \mathrm{NC}$ & 2 & 1 & $2-$ & $22-$ & $; 1 \mathrm{~N}$ & 2 & $2 \mathrm{CN}$ & $1 \mathrm{~N} / 3$ & $1 \mathrm{C}$ & $2-\mathrm{C} / 3$ & $1 \mathrm{C}$ & $2-/ ; 1$ & $2-\mathrm{CN}$ \\
\hline PI 605103 & Group 2 & 0 & 0 & 0 & 0 & 0 & 0 & $; 1 / ; 13$ & 0 & 0 & 0 & 0 & 0 & 0 & 0 & 0 & 0 \\
\hline PI 605132 & Group 2 & 0 & 0 & 0 & 0 & 0 & 0 & 0 & 0 & 0 & 0 & ; & 0 & 0 & 0 & 0 & 0 \\
\hline PI 611887 & Group 2 & $0 ; 1$ & 0 & 0 & 0 & 0 & 0 & 0 & 0 & $0 / 1 ; / 3$ & 0 & $0 ; / 3-$ & 0 & 0 & $0 ; / 1$ & 0 & 0 \\
\hline PI 611899 & Group 2 & $2-$ & $2-$ & $; 1 \mathrm{CN}$ & 1 & $2-$ & $1 \mathrm{C}$ & $22-3$ & 1 & $2-$ & $2-$ & $1 ; \mathrm{N}$ & $2-$ & $2-$ & $2-\mathrm{C}$ & $2-$ & $2-$ \\
\hline PI 611915 & Group 2 & 1 & 0 & 0 & 0 & 1 & 1 & 31 & 1 & $0 / 1$ & $; 1+/ 0$ & $; 1+$ & 0 & 0 & $; 1$ & 0 & 0 \\
\hline PI 611932 & Group 2 & $1 \mathrm{~N}$ & $0 ; / 1$ & 0 & 0 & $; 1$ & $2-$ & 1 & $2-\mathrm{C}$ & ; & $2-$ & $; 1$ & ; & 0 & 0 & - & $2-$ \\
\hline PI 605079 & Group 3 & $22+$ & - & 2 & - & 2 & $2+$ & $3+$ & $3+$ & 32 & $3+$ & 3 & 4 & 2 & $2+$ & 1 & 1 \\
\hline PI 605321 & Group 3 & 2 & 2 & 2 & 2 & 2 & $2-$ & - & $3+$ & 4 & 3 & 3 & 2 & 2 & 2 & 2 & 2 \\
\hline PI 604884 & Group 4 & $22-$ & $22-$ & $1 \mathrm{C}$ & 2 & 1 & - & $22+$ & $2+2$ & 2 & 3 & 3 & - & 1 & - & - & $2+$ \\
\hline PI 605094 & Group 5 & $0 ; 1 \mathrm{~N}$ & $22-\mathrm{CN}$ & $2-\mathrm{CN}$ & 2 & 2 & $2-\mathrm{C}$ & $3+$ & 3 & $2-;$ & 2 & $3+$ & $3+$ & 3 & $2+3$ & $2 / 3+$ & $2-\mathrm{C} / 3$ \\
\hline PI 605098 & Group 6 & $22+$ & 2 & 22-LIF & 2 & 2 & $2+$ & $2+$ & $2+$ & $2 ; \mathrm{C}$ & $2+$ & 2 & 2 & $3+$ & 3 & 2 & 2 \\
\hline PI 605246 & Group 7 & $2 / 0$ & 2 & $2-$ & 2 & $2-$ & 2 & $3+$ & 01 & 3 & 4 & $3+$ & $3+$ & $3+$ & - & $3+$ & $2 / 0 ; / 4$ \\
\hline
\end{tabular}

a Seedlings were scored using the seedling IT scale created by Stakman et al. (66). For an explanation of stem rust race nomenclature, see Roelfs and Martens (57).

b Symbols: / = separates different IT within a replication, $\mathrm{C}=$ excessive chlorosis, $\mathrm{N}=$ excessive necrosis, $\mathrm{LIF}=$ low infection frequency, $+=$ excessive pustule size for category, and $-=$ diminished pustule size for category (57).

${ }^{c}$ Accessions are grouped according to shared infection type patterns. 
PI 611932) had chromosome counts of $2 n=42$ in initial examinations and were selected for analysis using GISH and FISH (Fig. 2). The ITs of these accessions are displayed in Table 6 . The alien parent in the four selected accessions is the decaploid tall wheatgrass, T. ponticum $\left[2 n=10 \times=70\right.$; genome JJJJJJJ $\left.J^{\mathrm{S}} \mathrm{J}^{\mathrm{S}} \mathrm{J}^{\mathrm{s}}\right]$ (4). GISH-FISH analysis revealed that three accessions (PI 604981, PI 605286, and PI 611932) were disomic substitutions (20" + 1" E) (Fig. 2A, C, and D). PI 604981 was a mixture of plants with $2 n=42$ or 41 ; some had a pair of $T$. ponticum chromosomes substituting the wheat 2D pair and some contained no alien chromosomes. All analyzed plants had rearranged wheat chromosomes: telosomes and dicentric or translocation chromosomes involving 7A and an unknown D chromosome. Only one plant each of PI 605286 and PI 611932 was analyzed. Each had a pair of $T$. ponticum chromosomes substituting for wheat chromosome pairs 2D and 6D, respectively, (Fig. 2C and D). PI 605057 was a mixture of plants with chromosome numbers $2 n=$ 44,43 , and 41 . Four of six plants analyzed were disomic substitution or additions $(20 "+2$ " E) with $2 n=44$ and chromosome pair $2 \mathrm{D}$ absent (Fig. 2B). Wheat chromosome pair 2D was absent in PI 604981, PI 605057, and PI 605286.

\section{Discussion}

The analysis of 152 resistant accessions of the W. J. Sando collection and their reactions to eight races of $P$. graminis $\mathrm{f}$. sp. tritici revealed multiple significant positive correlations. The results of the Pearson's $r$ analysis and those of the MCA teased apart different relationships among the races of stem rust used in this study. The key factors affecting race clustering in MCA were virulence (more virulent and less virulent) and whether a race was virulent or avirulent on Sr31. Although resistances to races RKQQC and QTHJC were distinctly clustered in the MCA, reactions to both races were correlated significantly with one or more races in the Ug99 race group using Pearson's $r$. Also, North American races (TTTTF, TPMKC, QTHJC, and RKQQC) separated into distinct clusters in the MCA but showed varying degrees of correlation when compared using Pearson's $r$. The genetic relationship among these races has not yet been determined but recent advances in the genetics of $P$. graminis $\mathrm{f}$. sp. tritici, such as a published genome and single-nucleotide polymorphism assay, may reveal underlying relationships that could explain the phenotypic relationships observed in this study $(8,67)$. Overall, the various degrees of clustering and correlation observed indicate that $\mathrm{Sr}$ genes effective against multiple races may be present in the W. J. Sando collection.

Accessions that displayed resistance to each of three races in the Ug99 race group (TTKSK, TTKST, and TTTSK) segregated into seven groups based on race-specific IT patterns. Some accessions displayed different ITs between replicate assays with a single $P$. graminis f. $\mathrm{sp}$. tritici race. Multiple accessions within this collection that were examined cytogenetically displayed interseedling chromosomal variation (see below). The different ITs displayed by a single accession to a single race in this study might be explained by the presence of different chromosome complements within the same accession (see below). It is also possible that slight environmental variability among replicates may have influenced individual accession reactions to a single race of the stem rust pathogen $(40,42)$. Group 1 accessions were characterized by their additional resistance to race RKQQC and susceptibility to the remaining races. Races TTKSK, TTKST, TTTSK, and RKQQC are all avirulent to the stem rust resistance gene $\operatorname{SrTmp}(19,20)$. This gene was introduced into U.S. winter wheat germplasm with the arrival of Turkey hard red winter wheat in 1874 and is a widely distributed $\mathrm{Sr}$ gene in hard red winter wheat germplasm (56). However, race QTHJC, to which group 1 accessions are susceptible, is also avirulent on SrTmp. All group 1 accessions exhibited ITs of " $3+$ " or greater when screened with QTHJC, except accessions PI 605016 and PI 611927, which exhibited ITs of "1+" and "2-", respectively, in one of two replicate assays. Phenotypic data indicated that $\operatorname{SrTmp}$ is not the $\mathrm{Sr}$ gene conferring resistance in group 1 accessions. Accessions in group 1 have several alien species listed in their pedigrees, including T. ponticum, Secale cereale, Triticum turgidum subsp. dicoccum, and Aegilops ventricosa. The lack of a single, consistent alien parent in group 1 pedigrees suggests that the $S r$ genes conditioning resistance in this group may be from $T$. aestivum.
In addition to $S r T m p$, there are four T. aestivum-derived $\mathrm{Sr}$ genes effective against the Ug99 race group: $\mathrm{Sr} 28, \mathrm{Sr} 42, \mathrm{Sr} 57 / \mathrm{Lr} 34$, and $\mathrm{Sr} 9 \mathrm{~h}$ (formerly $\mathrm{SrWeb}$ ) (59). Sr28, from U.S. 'Kota' wheat, is not effective against RKQQC and conditions an IT response of ";3", not "2", to TTKSK, TTKST, and TTTSK $(38,58)$. Sr57/Lr34 confers adult plant resistance only $(29,30)$. However, $\mathrm{Sr} 42$, from the Japanese cultivar 'Norin 40', shares the same resistance and susceptibility pattern as group 1 (14). The expected low IT for Sr42 is ";1" to "2" (14). Lopez-Vera et al. (36) suggested that $S r 42$ and $\operatorname{SrTmp}$ may be the same gene or alleles of the same gene. However, SrTmp is effective against race QTHJC to which Norin 40, donor of $S r 42$, is susceptible (14). $S r 9 h$ also shares the same pattern as group $1(15,59)$. Therefore, current data cannot differentiate the race-specific IT pattern of group 1 accessions from the patterns displayed by those lines with $\mathrm{Sr} 42$ and $\mathrm{Sr} 9 \mathrm{~h}$.

Eight of nine accessions in group 2 have Thinopyrum ponticum listed in their pedigree, while one contains T. intermedium. T. ponticum is the donor of stem rust resistance genes $S r 24, S r 25, S r 26$, and $S r 43$, each effective against many races of $P$. graminis f. sp. tritici $(7,32,40,42)$. Sr24 is not effective against race TTKST and each group 2 accession displayed resistant ITs against this race. $S r 25$ provides marginal resistance to race TRTTF, expressing an IT of " $2+3-$ "' in a 'Little Club' background; however, this is still within the range of low ITs expected for this gene $(38,44)$. PI 604981 displayed mixed reactions to race TRTTF and also amplified the $S r 25$-associated amplicon when screened with the PCR marker $G b$, developed by Prins et al. (52). PI 611899 also displayed a higher IT to race TRTTF in one replication but has not been screened with Sr25-linked molecular markers. All other accessions in group 2 displayed much lower ITs than that conferred by $\operatorname{Sr} 25$ when challenged with race TRTTF.

$\mathrm{Sr} 43$ is a temperature-sensitive gene, becoming ineffective at $26^{\circ} \mathrm{C}$, and also displays a higher IT (" $\left.12 ; / ; 12 "\right)$ to race QTHJC than that exhibited by group 2 accessions, except PI 611899 and 604986 (42). Because the screenings in this study were not conducted at temperatures $>26^{\circ} \mathrm{C}$, we cannot rule out the possibility that group 2 accessions may possess $\mathrm{Sr} 43$.

Sr26 has an expected low IT that ranges from ";," to "2-" and may also be a candidate for the gene providing the resistance observed in accessions derived from T. ponticum (40). Accession PI 611932 amplified the Sr26associated fragment when screened with the multiplex PCR markers BE518379/Sr26\#43 (32,37). PI 604981 was the only other group 2 accession screened with the same multiplex marker, and failed to amplify the Sr26-associated amplicon. Further screening at temperatures $>26^{\circ} \mathrm{C}$ as well as more extensive genotyping will need to be conducted to determine the resistance genes present in group 2. However, molecular and phenotypic analyses, as well as cytogenetic results discussed below, indicate that group 2 accession PI 611932 likely possesses $\operatorname{Sr} 26$.

PI 605132 is the only accession in group 2 with $T$. intermedium in its pedigree. T. intermedium is the donor of $\mathrm{Sr} 44$, a resistance gene effective against races TTKSK, TTKST, and TTTSK but susceptible to TRTTF (33). Liu et al. (33) postulated that $T$. intermedium chromosome segment $7 \mathrm{~J} \# 1 \mathrm{~L}$ harbors an unknown stem rust resistance gene that does confer resistance to race TRTTF. PI 605132 was found to have a chromosome composition of $2 n=54$ and may possess multiple unknown stem rust resistance genes located on $T$. intermedium chromatin.

Group 3 accessions PI 605079 and PI 605321 displayed IT patterns that were indistinguishable from those of lines possessing SrTmp. PI 605079 was more resistant (IT = "1;") to RKQQC than the expected low IT ("2" to " 23 ") for SrTmp but this may have been due to experimental variance (slight temperature variation or scorer subjectivity). It is possible that resistance in these accessions is derived from $S r T m p$; however, additional $S r$ genes may be present in these accessions. Allelism tests could determine whether SrTmp is the source of resistance in these accessions (45).

Accessions in groups 4 through 7 each contained a single accession with an IT pattern that could not be matched to any known single stem rust resistance gene. Each accession had a unique alien parent within its pedigree. More work would need to be done to determine the nature of resistance of each line. However, accessions PI 604884 PI 605094, PI 605098, and PI 605246 may possess new resistance genes effective against the Ug99 race group. 
Only two of four accessions analyzed using GISH-FISH amplified alleles associated with known stem rust resistance genes derived from T. ponticum. Recent work with Thinopyrum spp. or Thinopyrumwheat partial amphiploids have found that false positives are common when using molecular markers designed from hexaploid bread wheat to screen Thinopyrum material $(69,75)$. Zheng et al. (75) found that some markers were species or genus specific when used to screen five Thinopyrum spp. PI 604981 amplified the $S r 25$-associated allele when screened with marker $G b$. Marker $G b$ has been verified in multiple studies as amplifying a 130-bp product only in wheat cultivars known to possess $\operatorname{Sr} 25(32,73)$. However, no cultivars tested in these studies possessed whole chromosomes from a Thinopyrum sp., as does PI 604981. Additionally, all species of Thinopyrum tested by Zheng et al. (75), except $T$. junceum, possessed some accessions that were positive for the $\operatorname{Sr} 25$ amplicon. Because $\operatorname{Sr} 25$ has been shown to be derived from $T$. ponticum, this may indicate that $G b$ detects a common Thinopyrum locus regardless of the presence of $S r 25$ (24,39). Phenotypic evidence indicates that the resistance observed in PI 604981 (";" to ";3") differs from that expected of $\operatorname{Sr} 25$ ("1" to "23") (40). The variability in both molecular and phenotypic evidence indicates that PI 604981 either does not carry $S r 25$ or possesses a unique allele of this resistance gene. Accession PI 611932, which amplified the Sr26-associated amplicon, was discussed above and is discussed below.

Cytogenetic analysis in this study of selected W. J. Sando accessions confirmed previous reports of the mixed ploidy and chromosome complements present in this collection $(5,43)$. Each accession analyzed using FISH possessed $T$. ponticum as the alien species in the listed pedigree. Stem rust resistance genes $\mathrm{Sr} 24, \mathrm{Sr} 25, \mathrm{Sr} 26$,
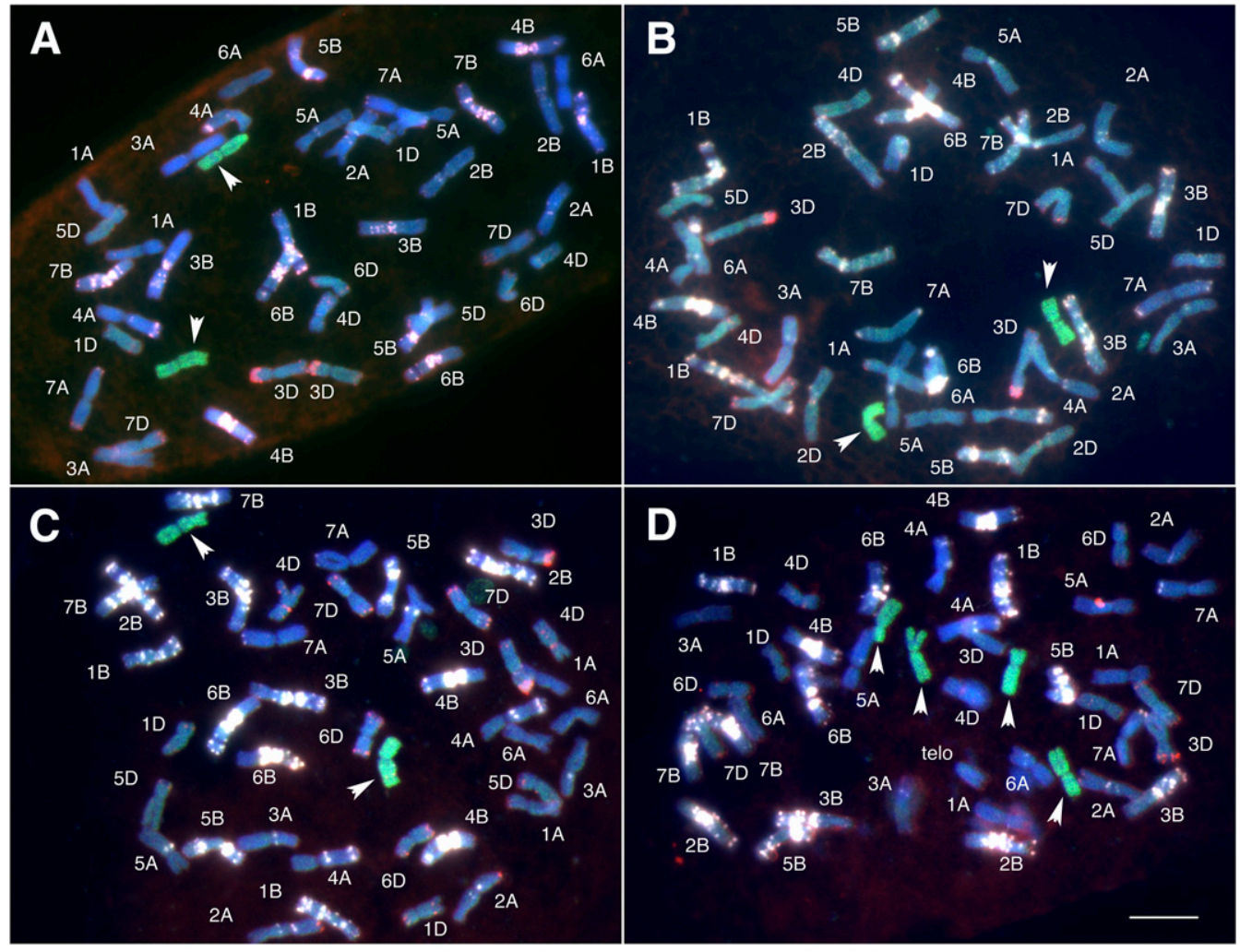

Fig. 2. Images of combined genomic in situ hybridization (GISH) and fluorescence in situ hybridization (FISH) of W. J. Sando collection wheat accessions PI $604981, \mathrm{PI} 605057$, PI 605286, and PI 611932. GISH with Thinopyrum ponticum genomic DNA as a probe detected one pair of $T$. ponticum chromosomes (marked by arrowheads) in accessions with $2 n=$ 42 chromosomes: A, PI 604981; B, PI 611932; and C, PI 605286; and two pairs in an accession with 2n =44, D, PI 605057. FISH was conducted with oligonucleotide probes GAA and pAs1, and produced chromosome-specific patterns that allowed the identification of individual wheat chromosomes (6). In accessions PI 604981, PI 605286, and PI 605057, wheat chromosome pair 2D is missing; in PI 611932, chromosome pair 6D is missing. It was assumed that the missing wheat chromosomes were substituted by T. ponticum homeologs. In PI 605057, the additional T. ponticum pair belongs to an unknown homeologous group. Chromosomes were counterstained with 4',6-diamidino-2-phenylindole solution and fluoresce blue. GAA repeats are white, pAs1 repeats are red, and T. ponticum chromosomes are stained green. Scale bar $=10 \mu \mathrm{m}$.

Table 6. Infection types (IT) of W. J. Sando wheat accessions PI 604981, PI 605057, PI 605286, and PI 611932 to eight races of Puccinia graminis f. sp. tritici

\begin{tabular}{|c|c|c|c|c|c|c|c|c|c|c|c|c|c|c|c|c|}
\hline \multirow[b]{3}{*}{ Accession $^{c}$} & \multicolumn{16}{|c|}{ Race $^{b}$} \\
\hline & \multicolumn{2}{|c|}{ TTKSK } & \multicolumn{2}{|c|}{ TTKST } & \multicolumn{2}{|c|}{ TTTSK } & \multicolumn{2}{|c|}{ TRTTF } & \multicolumn{2}{|c|}{ TTTTF } & \multicolumn{2}{|c|}{ TPMKC } & \multicolumn{2}{|c|}{ QTHJC } & \multicolumn{2}{|c|}{ RKQQC } \\
\hline & Rep 1 & $\operatorname{Rep} 2$ & Rep 1 & Rep 2 & Rep 1 & $\operatorname{Rep} 2$ & Rep 1 & $\operatorname{Rep} 2$ & $\operatorname{Rep} 1$ & $\operatorname{Rep~} 2$ & Rep 1 & $\operatorname{Rep} 2$ & $\operatorname{Rep} 1$ & $\operatorname{Rep} 2$ & $\operatorname{Rep} 1$ & $\operatorname{Rep} 2$ \\
\hline PI 604981 & 0 & $; 1$ & 0 & $; 1$ & 2 & 0 & $3-; / 0$ & $0 ; 1 / ; 13$ & ; & 0 & ;3 & $0 ; 3$ & 1 & 1 & 0 & 0 \\
\hline PI 605057 & $0 ; 3$ & 0 & - & 31 & 3 & 3 & $2 \mathrm{LIF}$ & $2-12-; / 3$ & 2 & $1+\mathrm{N}$ & 3 & 3 & $1 ;$ & $1+$ & $1+$ & $3 \mathrm{LIF}$ \\
\hline PI 605286 & $0 ; 3$ & 0 & - & $0 ; / 3$ & 1 & 1 & $0 ; / 0 ; 1+$ & $0 ; / 1$ & 3 & $; 1 / 1+/ 4$ & ;11+ & 0 & 0 & 0 & $; 1$ & 0 \\
\hline PI 611932 & $1 \mathrm{~N}$ & $0 ; / 1$ & 0 & 0 & $; 1$ & $2-$ & 1 & $2-\mathrm{C}$ & ; & $2-$ & $; 1$ & ; & 0 & 0 & - & $2-$ \\
\hline
\end{tabular}

a Seedlings were scored using the seedling infection type scale created by Stakman et al. (66).

${ }^{\mathrm{b}}$ For an explanation of stem rust race nomenclature, see Roelfs and Martens (57). Symbols: / = separates different IT within a replication; C= excessive chlorosis;

$\mathrm{N}$ = excessive necrosis; LIF = low-infection frequency; $+=$ excessive pustule size for category; $-=$ diminished pustule size for category (57).

${ }^{c}$ Accessions were examined using genomic in situ hybridization and fluorescence in situ hybridization $(6,22,74)$. 
and $S r 43$ are all derived from T. ponticum $(12,27,40)$. Both $S r 25$ and $\mathrm{Sr} 43$ are derived from $T$. ponticum group 7 chromosomes $(12,27)$. Only PI 604981 amplified the expected product when screened with $S r 25$ marker Gb. Sr25 is located on a T. ponticum group 7 chromosome and, although only chromosome pair 2D is missing from PI 604981, each plant examined of this accession also possessed telosomes and dicentric or translocation chromosomes involving 7A and an unknown D chromosome (11). The unknown chromosome involved was identified as belonging to the $\mathrm{D}$ genome; the only $T$. ponticum genetic material in this accession is the chromosome pair replacing 2D. Because marker $G b$ has only been tested in adapted Triticum aestivum lines, it is possible that $G b$ amplifies non-Sr25 loci located in other regions of the Thinopyrum ponticum genome. Also, see the section described above on recent work with Thinopyrum germplasm and molecular markers. Cytogenetic evidence supports the likelihood that PI 604981 does not possess $S r 25$.

$\mathrm{Sr} 43$ is derived from a $T$. ponticum $7 \mathrm{el}_{2}$ chromosome and was transferred to wheat chromosome 7D $(23,28)$. Because all accessions examined were fertile, it is assumed, along with Knott et al. (28), that the $T$. ponticum chromosomes found in these accessions are homeologous with the chromosomes they replaced. Because no accession was missing wheat group 7 chromosomes, it is unlikely that the $T$. ponticum chromosome carrying $\mathrm{Sr} 43$ is the source of TTKSK resistance in these accessions.

Sr24, while effective against TTKSK (Ug99), is ineffective against TTKST, to which these accessions, except PI 605057, were resistant. However, PI 605286 exhibited a mixed reaction, " $0 ; / 3$ ", to race TTKST. In contrast, PI 604981 and PI 611932 exhibited highly resistant ITs when inoculated with TTKST. Sr24 was transferred from a group $3 \mathrm{~T}$. ponticum chromosome to chromosome $3 \mathrm{D}$ of wheat and has also been transferred to the short arm of wheat chromosome 1B $(16,37,68)$. PI 605286 did not amplify the $S r 24$-associated fragment when screened with PCR marker Xbarc71 identified by Mago et al. (37). Yu et al. (73) have successfully used this marker to genotype 228 wheat lines from the International Maize and Wheat Improvement Center, the International Center for Agricultural Research in Dry Areas, China, and other miscellaneous origins for the presence of $S r 24$. However, despite the absence of molecular data, screening results remain inconclusive regarding whether PI 605286 possesses $\mathrm{Sr} 24$ due to potential false negatives when using molecular markers designed from a specific $T$. ponticum translocation $(69,75)$.

PI 605057 was susceptible to races TTKST, TTTSK, and TPMKC and exhibited a resistant reaction in one replicate test and a susceptible reaction in another replicate test to race RKQQC. All known $\mathrm{Sr}$ genes derived from $T$. ponticum are resistant to these races $(\mathrm{Sr} 24$ is not effective against TTKST) $(32,72)$. To our knowledge, no known $\mathrm{Sr}$ gene shares this resistance and susceptibility pattern, which may indicate either novel $S r$ genes or new alleles of known $S r$ genes, or a heterogeneous structure of the PI 605057 population.

Sr26 was transferred from the long arm of a T. ponticum group 6 chromosome to wheat chromosome $6 \mathrm{~A}(25,26)$. In GISH analysis, PI 611932 was shown to possess a single pair of $T$. ponticum chromosomes and lacked wheat chromosome group $6 \mathrm{D}$, indicating that the $T$. ponticum chromosomes may be group 6 chromosomes possessing Sr26. PI 611932 also possessed a possible T6AS.6AL/6DL translocation. Phenotypic, molecular, and cytogenetic data in this study indicated that $S r 26$ is the resistance gene in PI 611932 but no allelism tests have been conducted to confirm this. Accessions PI 605057 and PI 605286, and possibly PI 604981, may have uncharacterized stem rust resistance genes effective against the $\mathrm{Ug} 99$ race group. Chromosome engineering efforts are currently underway to reduce the size of alien chromatin in these accessions using a homozygous phlb line developed at Kansas State University Wheat Genetics Resource Center (13).

The W. J. Sando collection is known to harbor valuable resistance genes to multiple diseases effecting wheat production. Though individual lines had been characterized for their reaction to stem rust, to our knowledge, no published data existed characterizing the entire collection. This study resulted in characterizing the entire collection for stem rust resistance using eight races of $P$. graminis $\mathrm{f}$. sp. tritici. Furthermore, the 29 accessions identified with resistance to three races within the $\mathrm{Ug} 99$ race group are a valuable resource in the fight against stem rust. Future work with this germplasm should proceed more efficiently with the aid of this screening. Of the 29 accessions resistant to Ug99 races, 25 could not be distinguished from known $\mathrm{Sr}$ genes; however, future work may show that some accessions possess new genes or alleles. Cytogenetic techniques identified promising resistant accessions, three of which are postulated to contain new sources of resistance. Introgression of these resistance genes into adapted wheat germplasm will provide additional tools for breeding resistant wheat cultivars. Altogether, seven accessions were identified in this study as candidates possessing novel stem rust resistance.

\section{Acknowledgments}

This research was supported by the USDA-ARS National Plant Disease Recovery System and the Durable Rust Resistance in Wheat project managed by Cornell University, and funded by the Bill and Melinda Gates Foundation and the United Kingdom Department for International development. We thank X. Cai and X. Zhu of North Dakota State University for their assistance with the cytogenetic analysis of PI 611899, and H. Bockelman (USDA-ARS) for providing seed of the accessions.

\section{Literature Cited}

1. Banks, P. M., Xu, S. J., Wang, R., and Larkin, P. J. 1993. Varying chromosome composition of 56-chromosome wheat $\times$ Thinopyrum intermedium partial amphiploids. Genome 36:207-215.

2. Benzécri, J.-P. 1973. L’Analyse des Données. Dunod, Paris.

3. Blasius, J., and Greenacre, M. 2006. Correspondence analysis and related methods in practice. Pages 4-39 in: Multiple Correspondence Analysis and Related Methods. J. Blasius and M. Greenacre, eds. CRC Press, Boca Raton, FL.

4. Chen, Q., Conner, R. L., Laroche, A., and Thomas, J. B. 1998. Genome analysis of Thinopyrum intermedium and Thinopyrum ponticum using genomic in situ hybridization. Genome 41:580-586.

5. Cox, C. M., Murray, T. D., and Jones, S. S. 2002. Perennial wheat germ plasm lines resistant to eyespot, Cephalosporium stripe, and wheat streak mosaic. Plant Dis. 86:1043-1048.

6. Danilova, T. V., Friebe, B., and Gill, B. S. 2012. Single-copy gene fluorescence in situ hybridization and genome analysis: $A c c-2$ loci mark evolutionary chromosomal rearrangements in wheat. Chromosoma 121:597-611.

7. Dundas, I. S., Anugrahwati, D. R., Verlin, D. C., Park, R. F., Bariana, H. S., Mago, R., and Islam, A. K. M. R. 2007. New sources of rust resistance from alien species: Meliorating linked defects and discovery. Aust. J. Agric. Res. 58:545-549

8. Duplessis, S., Cuomo, C. A., Lin, Y.-C., Aerts, A., Tisserant, E., VeneaultFourrey, C., Joly, D. L., Hacquard, S., Amselem, J., Cantarel, B. L., Chiu, R., Coutinho, P. M., Feau, N., Field, M., Frey, P., Gelhaye, E., Goldberg, J., Grabherr, M. G., Kodira, C. D., Kohler, A., Kües, U., Lindquist, E. A., Lucas, S. M., Mago, R., Mauceli, E., Morin, E., Murat, C., Pangilinan, J. L., Park, R., Pearson, M., Quesneville, H., Rouhier, H., Sakthikumar, S., Salamov, A. A., Schmutz, J., Selles, B., Shapiro, H., Tanguay, P., Tuskan, G. A., Henrissat, B., Van de Peer, Y., Rouzé, P., Ellis, J. G., Dodds, P. N., Schein, J. E., Zhong, S., Hamelin, R. C., Grigoriev, I. V., Szabom, L. J., and Martin, F. 2011. Obligate biotrophy features unraveled by the genomic analysis of rust fungi. Proc. Natl. Acad. Sci. USA 108:9166-9171.

9. Faris, J. D., Xu, S. S., Cai, X., Friesen, T. L., and Jin, Y. 2008. Molecular and cytogenetic characterization of a durum wheat-Aegilops speltoides chromosome translocation conferring resistance to stem rust. Chromosome Res. 16:1097-1105.

10. Fisher, A. R. 1925. Statistical Methods for Research Workers. Oliver and Boyd, Edinburgh.

11. Friebe, B., Jiang, J., Knott, D. R., and Gill, B. S. 1994. Compensation indices of radiation-induced wheat-Agropyron elongatum translocations conferring resistance to leaf rust and stem rust. Crop Sci. 34:400-404.

12. Friebe, B., Jiang, J., Raupp, W. J., McIntosh, R. A., and Gill, B. S. 1996. Characterization of wheat-alien translocations conferring resistance to diseases and pests: Current status. Euphytica 91:59-87.

13. Friebe, B., Qi, L., Liu, C., Liu, W., and Gill, B. S. 2012. Registration of a hard red winter wheat genetic stock homozygous for $p h 1 b$ for facilitating alien introgression for crop improvement. J. Plant Regis. 6:121-123.

14. Ghazvini, H., Hiebert, C. W., Zegeye, T., Liu, S., Dilawari, M., Tsilo, T., Anderson, J. A., Rouse, M. N., Jin, Y., and Fetch, T. 2012. Inheritance of resistance to Ug99 stem rust in wheat cultivar Norin 40 and genetic mapping of Sr42. Theor. Appl. Genet. 125:817-824.

15. Hiebert, C. W., Fetch, T. G., and Zegeye, T. 2010. Genetics and mapping of stem rust resistance to Ug99 in the wheat cultivar Webster. Theor. Appl. Genet. 121:65-69.

16. Jiang, J., Friebe, B., and Gill, B. S. 1994. Chromosome painting of Amigo wheat. Theor. Appl. Genet. 89:811-813. 
17. Jin, Y., and Singh, R. P. 2006. Resistance in U.S. wheat to recent eastern African isolates of Puccinia graminis f. sp. tritici with virulence to resistance gene Sr31. Plant Dis. 90:476-480.

18. Jin, Y., Singh, R. P., Ward, R. W., Wanyera, R., Kinyua, M., Njau, P., Fetch, T., Pretorius, Z. A., and Yahyaoui, A. 2007. Characterization of seedling infection types and adult plant infection responses of monogenic $\mathrm{Sr}$ gene lines to race TTKS of Puccinia graminis f. sp. tritici. Plant Dis. 91: 1096-1099.

19. Jin, Y., Szabo, L. J., Pretorius, Z. A., Singh, R. P., Ward, R., and Fetch, T. 2008. Detection of virulence to resistance gene $S r 24$ within race TTKS of Puccinia graminis f. sp. tritici. Plant Dis. 92:923-926.

20. Jin, Y., Szabo, L. J., Rouse, M. N., Fetch, T., Pretorius, Z. A., Wanyera, R., and Njau, P. 2009. Detection of virulence to resistance gene Sr36 within the TTKS race lineage of Puccinia graminis f. sp. tritici. Plant Dis. 93:367-370.

21. Jones, S. S. 1995. Use of alien genes for the development of disease resistance in wheat. Annu. Rev. Phytopathol. 33:429-443.

22. Kato, A., Albert, P. S., Vega, J. M., and Birchler, J. A. 2006. Sensitive fluorescence in situ hybridization signal detection in maize using directly labeled probes produced by high concentration DNA polymerase nick translation. Biotech. Histochem. 81:71-78.

23. Kibirige-Sebunya, I., and Knott, D. R. 1983. Transfer of stem rust resistance to wheat from an Agropyron chromosome having a gametocidal effect. Can. J. Genet. Cytol. 25:215-221.

24. Kim, N. S., Armstrong, K., and Knott, D. R. 1993. Molecular detection of Lophopyrum chromatin in wheat-Lophopyrum recombinants and their use in the physical mapping of chromosome 7D. Theor. Appl. Genet. 85:561-567.

25. Knott, D. R. 1961. The inheritance of rust resistance. VI. The transfer of stem rust resistance from Agropyron elongatum to common wheat. Can. J. Plant Sci. 41:109-123.

26. Knott, D. R. 1968. Translocations involving Triticum chromosomes and Agropyron chromosomes carrying rust resistance. Can. J. Genet. Cytol. 10: 695-696.

27. Knott, D. R. 1988. The chromosome location of four recombinants between Agropyron chromosome $7 \mathrm{el}_{2}$ and a wheat chromosome. Genome 30:97-98.

28. Knott, D. R., Dvořák, J., and Nanda, J. S. 1977. The transfer to wheat and homoeology of an Agropyron elongatum chromosome carrying resistance to stem rust. Can. J. Genet. Cytol. 19:75-79.

29. Kolmer, J. A., Garvin, D. F., and Jin, Y. 2011. Expression of a Thatcher wheat adult plant stem rust resistance QTL on chromosome arm 2BL is enhanced by Lr34. Crop Sci. 51:526-533.

30. Krattinger, S. G., Lagudah, E. S., Spielmeyer, W., Singh, R. P., HuertaEspino, J., McFadden, H., Bossolini, E., Selter, L. L., and Keller, B. 2009. A putative $\mathrm{ABC}$ transporter confers durable resistance to multiple fungal pathogens in wheat. Science 323:1360-1363.

31. Leonard, K. J., and Szabo, L. J. 2005. Stem rust of small grains and grasses caused by Puccinia graminis. Mol. Plant Pathol. 6:99-111.

32. Liu, S., Yu, L.-X., Singh, R. P., Jin, Y., Sorrells, M. E., and Anderson, J. A. 2010. Diagnostic and co-dominant PCR markers for wheat stem rust resistance genes $S r 25$ and Sr26. Theor. Appl. Genet. 120:691-697.

33. Liu, W., Danilova, T. V., Rouse, M. N., Bowden, R. L., Friebe, B., Gill, B. S., and Pumphrey, M. O. 2013. Development and characterization of a compensating wheat-Thinopyrum intermedium Robertsonian translocation with Sr44 resistance to stem rust (Ug99). Theor. Appl. Genet. 126:1167-1177.

34. Liu, W., Jin, Y., Rouse, M., Friebe, B., Gill, B., and Pumphrey, M. O. 2011. Development and characterization of wheat-Ae. searsii Robertsonian translocations and a recombinant chromosome conferring resistance to stem rust. Theor. Appl. Genet. 122:1537-1545.

35. Liu, W., Rouse, M., Friebe, B., Jin, Y., Gill, B., and Pumphrey, M. O. 2011. Discovery and molecular mapping of a new gene conferring resistance to stem rust, Sr53, derived from Aegilops geniculata and characterization of spontaneous translocation stocks with reduced alien chromatin. Chromosome Res. 19:669-682.

36. Lopez-Vera, E. E., Nelson, S., Singh, R. P., Basnet, B. R., Haley, S. D., Bhavani, S., Huerta-Espino, J., Xoconostle-Cazares, B. G., Ruiz-Medrano, R., Rouse, M. N., and Singh, S. 2014. Resistance to stem rust Ug99 in six bread wheat cultivars maps to chromosome 6DS. Theor. Appl. Genet. 127:231-239.

37. Mago, R., Bariana, H. S., Dundas, I. S., Spielmeyer, W., Lawrence, G. J., Pryor, A. J., and Ellis, J. G. 2005. Development of PCR markers for the selection of wheat stem rust resistance genes $\mathrm{Sr} 24$ and $\mathrm{Sr} 26$ in diverse wheat germplasm. Theor. Appl. Genet. 111:496-504.

38. McIntosh, R. A. 1978. Cytogenetical studies in wheat. Heredity 41:71-82.

39. McIntosh, R. A., Dyck, P. L., and Green, G. J. 1977. Inheritance of leaf rust and stem rust resistances in wheat cultivars Agent and Agatha. Aust. J. Agric. Res. 28:37-45.

40. McIntosh, R. A., Wellings, C. R., and Park, R. F. 1995. Wheat Rusts: An Atlas of Resistance Genes. Commonwealth Scientific and Industrial Research Organization, Clayton South, Victoria, Australia.

41. Nenadic, O., and Greenacre, M. 2007. Correspondence analysis in R, with twoand three-dimensional graphics: The "ca" package. J. Stat. Softw. 20:1-13.

42. Niu, Z., Klindworth, D. L., Yu, G., Friesen, T. L., Chao, S., Jin, Y., Cai, X., Ohm, J. B., Rasmussen, J. B., and Xu, S. S. 2014. Development and characterization of wheat lines carrying stem rust resistance gene $\mathrm{Sr} 43$ derived from Thinopyrum ponticum. Theor. Appl. Genet. 127:969-980.
43. Oliver, R. E., Xu, S. S., Stack, R. W., Friesen, T. L., Jin, Y., and Cai, X 2006. Molecular cytogenetic characterization of four partial wheatThinopyrum ponticum amphiploids and their reactions to Fusarium head blight, tan spot, and Stagonospora nodorum blotch. Theor. Appl. Genet. 112:1473-1479.

44. Olivera, P. D., Jin, Y., Rouse, M., Badebo, A., Fetch, T., Jr., Singh, R. P., and Yahyaoui, A. 2012. Races of Puccinia graminis f. sp. tritici with combined virulence to $\operatorname{Sr} 13$ and $\operatorname{Sr} 9 e$ in a field stem rust screening nursery in Ethiopia. Plant Dis. 96:623-628.

45. Olivera, P. D., Millet, E., Anikster, Y., and Steffenson, B. J. 2008. Genetics of resistance to wheat leaf rust, stem rust, and powdery mildew in Aegilops sharonensis. Phytopathology 98:353-358.

46. Olson, E. L., Rouse, M. N., Pumphrey, M. O., Bowden, R. L., Gill, B. S., and Poland, J. A. 2013. Introgression of stem rust resistance genes SrTA10187 and SrTA10171 from Aegilops tauschii to wheat. Theor. Appl. Genet. 126: 2477-2484.

47. Olson, E. L., Rouse, M. N., Pumphrey, M. O., Bowden, R. L., Gill, B. S., and Poland, J. A. 2013. Simultaneous transfer, introgression, and genomic localization of genes for resistance to stem rust race TTKSK (Ug99) from Aegilops tauschii to wheat. Theor. Appl. Genet. 126:1179-1188.

48. Park, R., Fetch, T., Hodson, D., Jin, Y., Nazari, K., Prashar, M., and Pretorius, Z. 2011. International surveillance of wheat rust pathogens: Progress and challenges. Euphytica 179:109-117.

49. Pearson, K. 1895. Note on regression and inheritance in the case of two parents. Proc. R. Soc. Lond. 58:240-242.

50. Pretorius, Z. A., Singh, R. P., Wagoire, W. W., and Payne, T. S. 2000 Detection of virulence to wheat stem rust resistance gene Sr31 in Puccinia graminis f. sp. tritici in Uganda. Plant Dis. 84:203.

51. Pretorius, Z. A., Szabo, L. J., and Boshoff, W. 2012. First report of a new TTKSF race of wheat stem rust (Puccinia graminis f. sp. tritici) in South Africa and Zimbabwe. Plant Dis. 96:590.

52. Prins, R., Groenewald, J. Z., Marais, G. F., Snape, J. W., and Koebner, R. M. D. 2001. AFLP and STS tagging of $\operatorname{Lr19}$, a gene conferring resistance to leaf rust in wheat. Theor. Appl. Genet. 103:618-624.

53. Qi, L. L., Pumphrey, M. O., Friebe, B., Zhang, P., Qian, C., Bowden, R. L. Rouse, M. N., Jin, Y., and Gill, B. S. 2011. A novel Robertsonian translocation event leads to transfer of a stem rust resistance gene ( $\operatorname{Sr} 52)$ effective against race Ug99 from Dasypyrum villosum into bread wheat Theor. Appl. Genet. 123:159-167.

54. R Core Team. R: A language and environment for statistical computing Online publication. http://www.R-project.org

55. Reitz, L. P., Johnston, C. O., and Anderson, K. L. 1945. New combinations of genes in wheat $\times$ wheatgrass hybrids. Trans. Kans. Acad. Sci. 48: 151-159.

56. Roelfs, A. P. 1979. Low infection types produced by Puccinia graminis f. sp. tritici and wheat lines with designated genes for resistance. Phytopathology 69:722-730.

57. Roelfs, A. P., and Martens, J. W. 1988. An international system of nomenclature for Puccinia graminis f. sp. tritici. Phytopathology 78:526-533

58. Rouse, M. N., Nava, I. C., Chao, S., Anderson, J. A., and Jin, Y. 2012 Identification of markers linked to the race Ug99 effective stem rust resistance gene $\mathrm{Sr} 28$ in wheat (Triticum aestivum L.). Theor. Appl. Genet. 125:877-885

59. Rouse, M. N., Nirmala, J., Jin, Y., Chao, S., Fetch, T. G., Pretorius, Z. A., and Hiebert, C. W. 2014. Characterization of $\operatorname{Sr} 9 h$, a wheat stem rust resistance allele effective to Ug99. Theor. Appl. Genet. 127:1681-1688.

60. Rouse, M. N., Olson, E. L., Gill, B. S., Pumphrey, M. O., and Jin, Y. 2011 Stem rust resistance in Aegilops tauschii germplasm. Crop Sci. 51: 2074-2078

61. Singh, R. P., Hodson, D. P., Huerta-Espino, J., Jin, Y., Bhavani, S., Njau, P., Herrera-Foessel, S., Singh, P. K., Singh, S., and Govindan, V. 2011. The emergence of Ug99 races of the stem rust fungus is a threat to world wheat production. Annu. Rev. Phytopathol. 49:465-481.

62. Singh, R. P., Hodson, D. P., Jin, Y., Huerta-Espino, J., Kinyua, M. G., Wanyera, R., Njau, P. N., and Ward, R. W. 2006. Current status, likely migration and strategies to mitigate the threat to wheat production from race Ug99 (TTKS) of stem rust pathogen. CAB Rev. Perspect. Agric. Vet. Sci. Nutr. Nat. Resour. 1(054):1-13.

63. Singh, S., Singh, R. P., Bhavani, S., Huerta-Espino, J., and Eugenio, L.-V. E 2013. QTL mapping of slow-rusting, adult plant resistance to race Ug99 of stem rust fungus in PBW343/Muu RIL population. Theor. Appl. Genet. 126:1367-1375

64. Smith, D. C. 1942. Intergeneric hybridization of cereals and other grasses. J. Agric. Res. 64:33-47

65. Smith, E. L., Schlehuber, A. M., Young, H. C., and Edwards, L. H. 1968 Registration of Agent wheat (Reg. No. 471). Crop Sci. 8:511-512.

66. Stakman, E. C., Stewart, D. M., and Loegering, W. Q. 1962. Identification of Physiologic Races of Puccinia graminis var. tritici. United States Department of Agriculture Agricultural Research Service, Beltsville, MD.

67. Szabo, L. J., Cuomo, C. A., and Park, R. F. 2014. Puccinia graminis. Pages 177-196 in: Genomics of Plant-Associated Fungi: Monocot Pathogens R. A. Dean, A. Lichens-Park, and C. Kole, eds. Springer, Berlin. 
68. The, T. T., Gupta, R. B., Dyck, P. L., Appels, R., Hohmann, U., and McIntosh, R. A. 1991. Characterization of stem rust resistant derivatives of wheat cultivar Amigo. Euphytica 58:245-252.

69. Turner, M. K., DeHaan, L. R., Jin, Y., and Anderson, J. A. 2013. Wheatgrasswheat partial amphiploids as a novel source of stem rust and Fusarium head blight resistance. Crop Sci. 53:1994-2005.

70. Wanyera, R., Kinyua, M. G., Jin, Y., and Singh, R. P. 2006. The spread of stem rust caused by Puccinia graminis f. sp. tritici, with virulence on Sr31 in wheat in eastern Africa. Plant Dis. 90:113.

71. Xu, S. S., Jin, Y., Klindworth, D. L., Wang, R. R. C., and Cai, X. 2009. Evaluation and characterization of seedling resistances to stem rust Ug99 races in wheat-alien species derivatives. Crop Sci. 49:2167-2175.

72. Yu, L.-X., Barbier, H., Rouse, M. N., Singh, S., Singh, R. P., Bhavani, S., Huerta-Espino, J., and Sorrells, M. E. 2014. A consensus map for
Ug99 stem rust resistance loci in wheat. Theor. Appl. Genet. 127: 1561-1581.

73. Yu, L.-X., Liu, S., Anderson, J. A., Singh, R. P., Jin, Y., Dubcovsky, J., Brown-Guidera, G., Bhavani, S., Morgounov, A., He, Z., HuertaEspino, J., and Sorrells, M. E. 2010. Haplotype diversity of stem rust resistance loci in uncharacterized wheat lines. Mol. Breed. 26: 667-680.

74. Zhang, P., Friebe, B., Lukaszewski, A. J., and Gill, B. S. 2001. The centromere structure in Robertsonian wheat-rye translocation chromosomes indicates that centric breakage-fusion can occur at different positions within the primary constriction. Chromosoma 110:335-344.

75. Zheng, Q., Klindworth, D. L., Friesen, T. L., Liu, A.-F., Li, Z.-S., Zhong, S., Jin, Y., and Xu, S. S. 2014. Characterization of species for wheat stem rust resistance and ploidy level. Crop Sci. 54:2663-2672. 